culture, show the first formation of oil-drops around the pyrenoids within the starch-sheath as well as surrounding the sheath; here the starch-sheath becomes narrower and thinner-evidently oil is secondarily formed from the primarily formed starchgrains in the sheath.
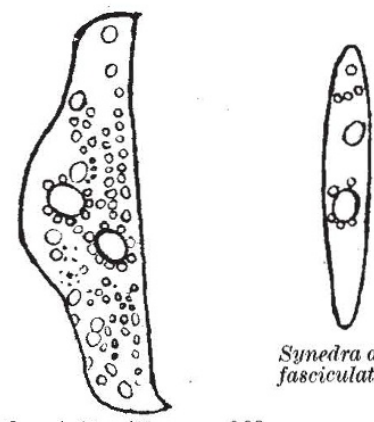

Synedra affinis var. fasciculata. $\times 720$

Rhopalodia gibba. $\times 360$

Fig. 1.

Thus, from these experiments it is held probable that pyrenoids serve as receptacles of appropriate enzymes for the syntheses of various food substances in such plants.

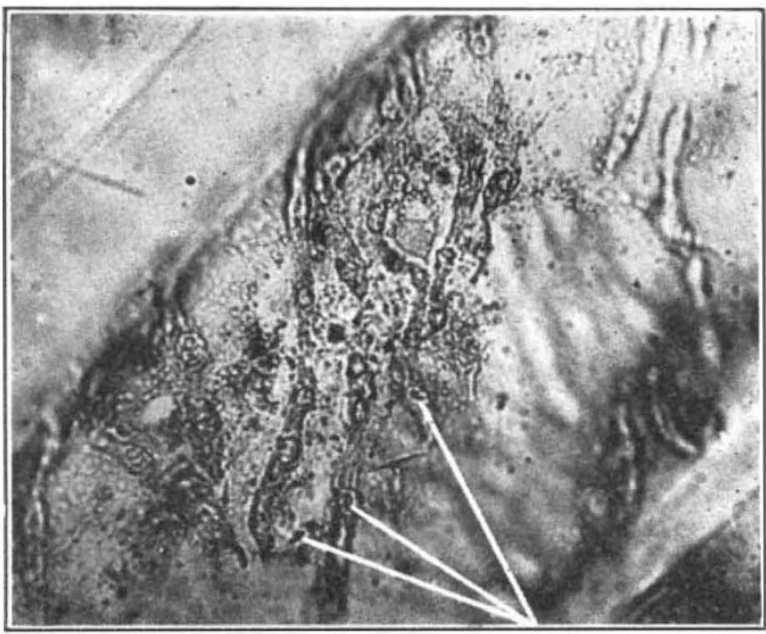

Fig. 2.

SPIROGYRA SP. Photomicrograph UNDER OII. IMMERSION LENS AND EYE-PIECE NO. 5; OIL-DROPS AROUND THE PYRENOYDS WITHIN THE STARCH-SHEATH ARE MARKED BY WHITE LINES.

The central portion of the pyrenoids gives the protein test with Millon's reagent, where a very faint pinkish stain is visible under the oil-immersion lens. In plants (both lower and higher) lacking in pyrenoids pinkish vacuoles are always found inside the plastids, and food substances are usually deposited in connexion with them. These pinkish vaeuoles are not found in old, disorganized or plasmolysed cells.

It is hoped to publish the details of the work soon.

Botanical Laboratory,

Carmichael Medical College, Calcutta.

June 10.

2 "Fresh Water Algæ of the United States" (1933).

2 Engler's “Nat. Pflanzenfam.", 2 (1928),

\section{Biography of W. H. Wollaston}

IN 1931 I appealed in NATURE ${ }^{1}$ for information for a biography of William Hyde Wollaston. Since then, probably all printed information of any importance has been supplemented by a large amount of unpublished material. In the collection of the latter, much of which is of great interest, I have received very generous help from many sources.

Various circumstances have delayed the work, but in a way I do not regret the delay, because from time to time fresh material has come to light. Only a few weeks ago a large collection of letters from Wollaston to E. D. Clarke (1769-1822), professor of mineralogy at Cambridge from 1808, was reported in a book. seller's catalogue, and is now in my possession. It is possible that other Wollaston material which readers of NATURE may know of is unknown to me. The dossier collected by Henry Warburton after Wollaston's death for the purpose of a biography was "lost", although I believe I have found a small fraction of it.

I am writing to record thus that the work is still in progress, and to issue one more appeal for information. Documents would be gratefully received by me, and would be returned by registered post as soon as copied; or, if correspondents would prefer that their documents were inspected under the ægis of an important library, Dr. T. Richards, librarian of the University College of North Wales, Bangor, where the section to which I belong of the Chemistry Department, University College, London, is enjoying hospitality, has kindly consented to take temporary charge of such papers.

10 Victoria Terrace, L. F. Gilbert. Beaumaris, Anglesey.

${ }^{2}$ NATURE, 127, 340 (1931). The date of Wollaston's birth was there stated as 1765 instead of 1766 .

\section{Mien of Science as Administrators}

IN a letter to Nature (May 31), R. A. Jones has well expressed the molluscan tendency of men of science to grow a shell and stay in it, and the difficulty of acquiring the arthropod ability to moult into an administrative stage. This difficulty exists in Canada also, but to a lesser degree, I think, than in England. The reaction to strong criticism may often be an invitation to "come and do it yourself, you who know so much".

It seems to be agreed that the peaceful penetration of government departments by men of scientific training and experience is desirable. I submit that for men of science engaged in 'near-economic' work such penetration is not difficult, given the will and political conscience to do so. Men of administrative experience are vulnerable on the side of economic development. As to the lack of administrative experience among men of science, which, as $\mathrm{Mr}$. Jones points out, is considered a serious obstacle, it seems to me that if a classical education is looked upon as a sound foundation for the conduct of the affairs of the native populations of Africa, then a knowledge of the quantum theory should be as good equipment for the administration of civilized communities.

Department of Zoology,

M. J. DUNBar. MeGill University, Montreal. 